\title{
Holocene paleoenvironmental implications of diatom and organic carbon records from the southeastern Kara Sea (Siberian Margin)
}

\author{
Yelena I. Polyakova ${ }^{\mathrm{a}}$, Ruediger Stein ${ }^{\mathrm{b}, *}$ \\ ${ }^{a}$ Department of Geography, Lomonosov Moscow State University, Vorobievy Gory, 119899 Moscow, Russia \\ ${ }^{\mathrm{b}}$ Alfred Wegener Institute for Polar and Marine Research, Columbusstrasse, 27568 Bremerhaven, Germany
}

Received 11 December 2002

\begin{abstract}
Diatom assemblages and organic carbon records from two sediment cores located within an estuarian bay of the inner Kara Sea trace changes in Yenisei River runoff and postglacial depositional environments. Paleosalinity and sea-ice reconstructions are based on modern relationships of local diatom assemblages and summer surface-water salinity. Approximately 15,500 cal yr B.P., rivers and bogs characterized the study area. When sea level reached the 38- to 40-m paleo-isobath approximately 9300 cal yr B.P., the coring site was flooded. From 9300-9100 cal yr B.P., estuarine conditions occurred proximal to the depocenter of fluvially derived material, and salinity was $<7-8$. Paleosalinity increased to $11-13$ by $7500 \mathrm{cal}$ yr B.P., following postglacial sea-level rise and the southward shift of the Siberian coast. Sharp decreases in diatom accumulation rates, total sediment, and organic carbon also occurred, suggesting the presence of brackish conditions and greater distance between the coast and study site. Maximum paleosalinity (up to 13) was recorded between 7500 and 6000 cal yr B.P., which was likely caused by the enhanced penetration of Atlantic waters to the Kara Sea. Stepwise decreases to modern salinity levels happened over the last $6000 \mathrm{cal}$ yr.
\end{abstract}

(C) 2004 University of Washington. All rights reserved.

Keywords: Paleosalinity; Paleo-river discharge; Sea-ice reconstructions

\section{Introduction}

The Kara Sea constitutes the western portion of the wide Siberian shelf that borders northern Eurasia (Fig. 1) and is regarded as a key area for the supply of fresh water and sea ice to the Arctic Ocean (Gordeev, 2000; Lisitzin and Vinogradov, 1995; Stein, 2000; Stein et al., 2003, 2004; Zakharov, 1996). The $\mathrm{Ob}$ and Yenisei rivers, which enter the Kara Sea, contribute approximately $1500 \mathrm{~km}^{3}$ of fresh water each year and approximately $40 \%$ of the total annual riverine discharge to the Arctic Ocean (Aagaard and Carmack, 1989; Gordeev, 2000; Rachold et al., 2003). These two rivers drain an area of $5 \times 10^{6} \mathrm{~km}^{2}$ or about half

\footnotetext{
* Corresponding author. Fax: +49 47148311580.

E-mail address: rstein@awi-bremerhaven.de (R. Stein).
}

of the Russian land mass. The discharge of suspended matter is smaller on a global scale than the freshwater outflow. However, they average $>30 \times 10^{6}$ tons/yr or approximately $30 \%$ of the suspended matter delivered by northern Eurasian rivers to the arctic shelves (Gordeev, 2000). Approximately $40 \%$ of dissolved and particulate organic carbon exported from northern Eurasia to the arctic shelves is contributed by rivers entering the Kara Sea (Gordeev, 2000; Rachold et al., 2003). Today, 90-95\% of the river sediment load is deposited in the estuaries of the $\mathrm{Ob}$ and Yenisei rivers and on the adjacent inner Kara sea shelf, where specific conditions occur in the "marginal filter" (i.e., the zone where fresh and marine waters mix; Lisitzin, 1995, 2002). Here, rapid sedimentation provides high-quality records of present and past land-ocean interactions in the Eurasian Arctic.

Changes in the abundances and composition of marine and freshwater diatom assemblages from river-proximal 


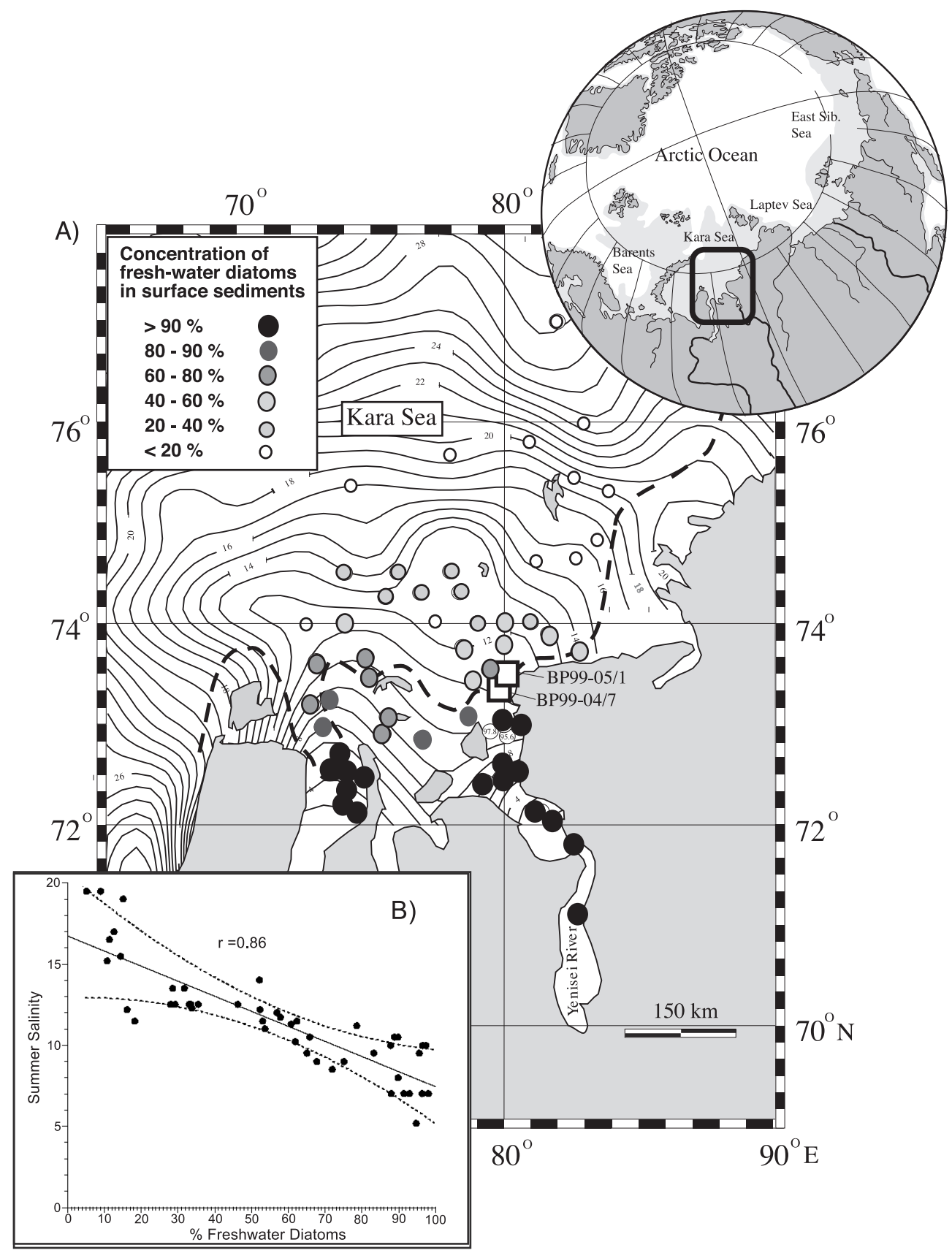

Figure 1. Relative distribution of freshwater diatoms in surface sediments of the Kara Sea and the outer Ob and Yenisei estuaries (after Polyakova, 2003). Salinity contour lines represent the mean interannual summer surface-water salinity in the Kara Sea based on 50 years of measurements (after Dmitrenko et al., 1999). The squares indicate the positions of cores BP99-04/7 and BP99-05/1. The inset (B) shows the correlation between the relative abundance of freshwater diatoms and summer surface-water salinity (salinity range of 5 to 20 ).

sediments trace shifts in past shelf environments of the arctic seas (Cremer, 1999a,b; Polyakova, 1994, 1997, 2003). Diatoms are important components both of the particulate organic matter that is transported onto shelves by rivers and of the phytoplankton production in the Kara Sea (Lisitzin et al., 1995; Makarevich et al., 2003; Nöthig et al., 2003; Usachev, 1968; Vedernikov et al., 1995). Like other micropaleontological (e.g., Matthiessen and Kraus, 2001; Matthiessen et al., 2000; Kraus et al., 2003) and biogeochemical tracers (e.g., Fahl and Stein, 1997, 1999; Stein and Fahl, 2003), diatom assemblages can identify and characterize different sources of organic carbon (i.e., terrestrial/freshwater vs. marine) in shelf sediments. Moreover, established linkages between hydrographical parameters (e.g., summer surface-water salinity, sea-ice conditions) and the composition of diatom assemblages extracted from surface sediments of the Kara Sea shelf (Fig. 1; Polyakova, 2003) help in reconstructing paleoenvironmental conditions.

Recently completed analyses of core-top sediments of the $\mathrm{Ob}$ and Yenisei estuaries and the adjacent inner Kara 
Sea shelf provide additional insights into the regional relationships of modern diatom assemblages and various environmental conditions (Polyakova, 2003). This knowledge was applied to two Holocene sedimentary records from the shallow, southeastern Kara Sea (Fig. 1). This area was influenced by extensive discharge of the Yenisei River, large postglacial shifts in sea level, and significant variation in the Yenisei River outflow (e.g., Stein et al., 2003). Because of the high sedimentation rates in these cores and the good-quality postglacial chronologies (Stein, 2001; Stein et al., 2003), we are able to describe for the first time the short-term variability in riverine discharge, paleosalinity, and ice conditions in the seas of the Eurasian arctic shelf.

\section{Material and methods}

Cores BP99-04/7 (04/5) and BP99-05/1 (Fig. 1) were obtained from the northeastern sector of the Yenisei estuary in 32.3 and $38.5 \mathrm{~m}$ of water, respectively, during the 1999 Russian-German expedition to the Kara Sea aboard the Research Vessel Akademik Boris Petrov. Core BP99-04/7 was collected with a gravity corer, but the upper $30 \mathrm{~cm}$ of sediment was lost. Consequently, a 30-cm-long multicorer (MUC) was used to collect undisturbed, uppermost sediments from the same location. This core (BP99-04/5) was correlated with the sedimentary sequence of core BP99-04/ 7 , thereby providing the complete recovery of $>8 \mathrm{~m}$ of generally homogeneous clayey silt. Core BP99-05/1, which is approximately $4 \mathrm{~m}$ long, consists of clayey silt $(0-1.4 \mathrm{~m})$ and sandy silt (1.4-4.1 m; Fig. 2, Stein et al., 2003).

Diatom samples were taken every $10 \mathrm{~cm}$ in cores BP9904/7 and BP99-05/1, whereas core BP99-04/5 was sampled every $5 \mathrm{~cm}$. Total organic carbon (TOC) was determined at 5 -cm intervals in both cores. After freeze-drying, bulk sediments were prepared for diatom analysis by treatment with $30 \% \mathrm{H}_{2} \mathrm{O}_{2}$ and $10 \% \mathrm{HCl}$. Diatom valves were then concentrated by decantation using distilled water. Residues were mounted in Naphrax (refractive index of 1.68) on glass slides (Battarbee, 1973). Valves were examined with a light microscope at $\times 1000$ magnification. Generally, approximately 300-400 specimens were counted in each sample, following procedures of Schrader and Gersonde (1978). Results were calculated as percentages and concentrations (number of valves/g of dry sediment). After grinding, TOC was determined with a LECO analyzer (analytical precision of approximately $\pm 0.02 \%$ absolute).

To examine temporal patterns of paleoenvironmental change and to calculate flux (accumulation) rates of bulk sediment and organic carbon, a precise chronology is necessary. Our age model is based primarily on bivalves, with AMS ${ }^{14} \mathrm{C}$ dates done at Leibniz-Labor für Altersbestmmungen, Kiel University (Table 1; see Stein et al., 2003, for additional details). Radiocarbon dates are $\delta^{13} \mathrm{C}$ normalized and corrected for a reservoir age of $440{ }^{14} \mathrm{C}$ yr

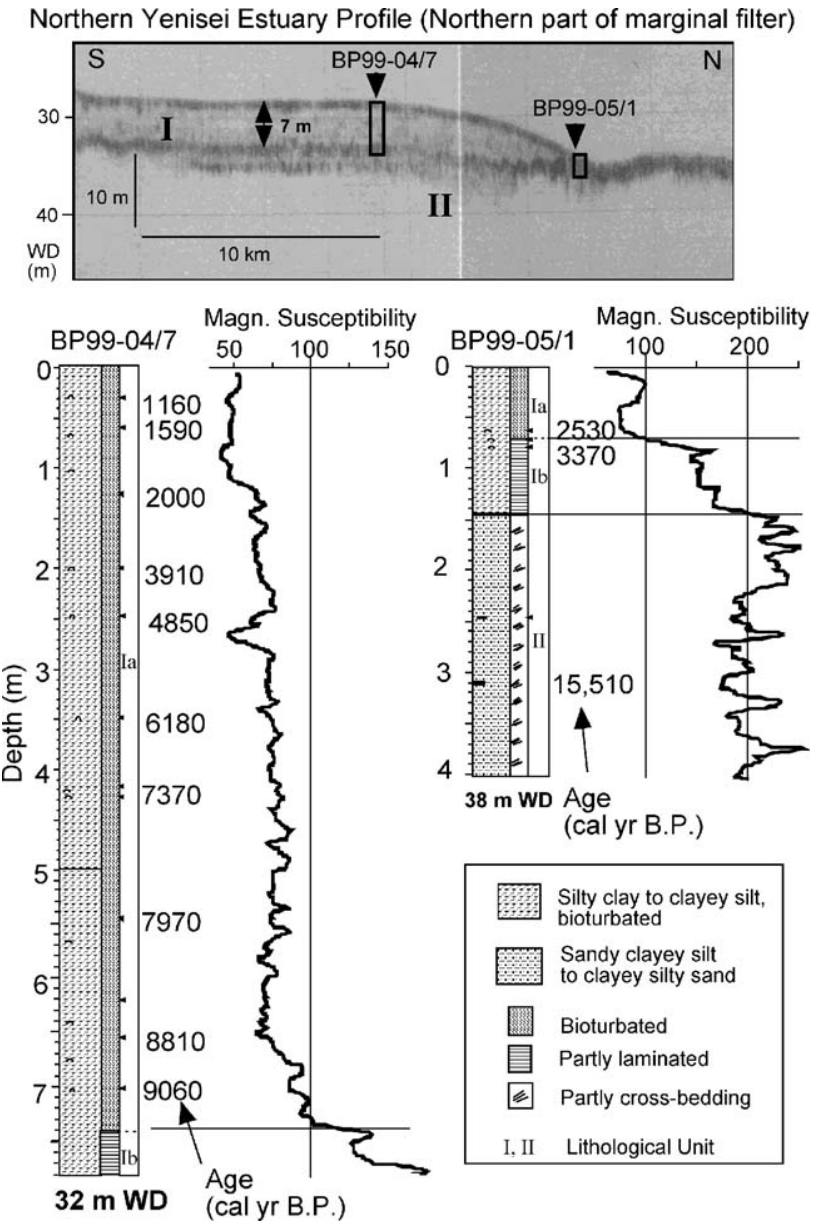

Figure 2. Lithology and magnetic susceptibility of cores BP99-04/7 and BP99-05/1, and ELAC sediment echograph profile from the northern Yenisei estuary. The magnetic susceptibility, measured with a Multi-Sensor Core Logging System, is defined as the dimensionless proportional factor of an applied magnetic field in relation to the magnetization in the sample (here expressed in $10^{-5} \mathrm{SI}$ units) and is indicative of the sedimentological/ mineralogical composition of the sediments (e.g., Kleiber and Niessen, 2000). Roman numbers indicate lithological units/subunits. Ages are given in cal yr B.P. (Table 1; Stein et al., 2003).

(Mangerud and Gulliksen, 1975). In addition to bivalve dates, one date from shrub wood was obtained for core BP99-05/1. AMS ${ }^{14} \mathrm{C}$ ages were calibrated with CALIB 4.1.2, Method A (Stuiver and Reimer, 1993; Stuiver et al., 1998). Ages of sample levels were determined with linear interpolation between the calibrated ${ }^{14} \mathrm{C}$ dates.

\section{Modern setting}

\section{Oceanography}

The Kara Sea, as is typical of Eurasian arctic marginal seas, has an area of which $75 \%$ is a flat, submerged plain. Water depths are mostly $<50 \mathrm{~m}$. The Kara Sea's formation has been governed mainly by sea-level fluctuations during the late Pleistocene and Holocene (Aibulatov, 2001; Pavlidis et al., 1998). Two paleovalleys of the $\mathrm{Ob}$ and Yenisei rivers trend northward across the submarine plain. 
Table 1

AMS ${ }^{14} \mathrm{C}$ dates from cores BP99-04/7 and BP99-05/1 (from Stein et al., 2003)

\begin{tabular}{|c|c|c|c|c|c|c|}
\hline $\begin{array}{l}\text { Core BP99-04/7 } \\
\text { (sample number) }\end{array}$ & $\begin{array}{l}\text { Material } \\
\text { dated }\end{array}$ & Depth $(\mathrm{cm})$ & $\begin{array}{l}{ }^{14} \mathrm{C} \text { age } \\
\left({ }^{14} \mathrm{C} \text { yr B.P. }\right)\end{array}$ & $\begin{array}{l}\text { Reservoir } \\
\text { correction } \\
\left({ }^{14} \mathrm{C} \text { yr }\right)\end{array}$ & $\begin{array}{l}\text { Corrected }{ }^{14} \mathrm{C} \text { age } \\
\left({ }^{14} \mathrm{C} \text { yr B.P. }\right)\end{array}$ & $\begin{array}{l}\text { Calibrated age } \\
\text { (cal yr B.P.) } \\
\text { (2-Std.dev.range) }\end{array}$ \\
\hline KIA-12781 & Bivalve & 29 & $1630 \pm 20$ & -440 & 1190 & 1159 (1131-1171) \\
\hline KIA-12782 & Bivalve & 57 & $2070 \pm 25$ & -440 & 1630 & $1586(1548-1616)$ \\
\hline KIA-10239 & Bivalve & 122.5 & $2430 \pm 30$ & -440 & 1990 & 2001 (1974-2050) \\
\hline KIA-10238 & Bivalve & 191 & $3980 \pm 30$ & -440 & 3540 & $3911(3870-3962)$ \\
\hline KIA-10237 & Bivalve & 246 & $4695 \pm 30$ & -440 & 4255 & $4847(4828-4868)$ \\
\hline KIA-10236 & Bivalve & 329 & $5800 \pm 40$ & -440 & 5360 & $6178(6158-6218)$ \\
\hline KIA-10235 & Bivalve & 420 & $6855 \pm 35$ & -440 & 6415 & 7325 (7295-7377) \\
\hline KIA-10234 & Bivalve & 432 & $6890 \pm 45$ & -440 & 6450 & 7373 (7315-7413) \\
\hline KIA-10233 & Bivalve & 530 & $7585 \pm 35$ & -440 & 7145 & 7975 (7947-8022) \\
\hline KIA-10232 & Bivalve & 632 & $8345 \pm 50$ & -440 & 7905 & 8845 (8766-8906) \\
\hline KIA-10231 & Bivalve & 658.5 & $8310 \pm 40$ & -440 & 7870 & 8810 (8716-8882) \\
\hline KIA-10230 & Bivalve & 700 & $8725 \pm 40$ & -440 & 8285 & 9059 (9010-9396) \\
\hline $\begin{array}{l}\text { Core BP99-05/1 } \\
\text { (sample number) }\end{array}$ & & Depth $(\mathrm{cm})$ & $\begin{array}{l}{ }^{14} \mathrm{C} \text { age } \\
\left({ }^{14} \mathrm{C} \text { yr B.P. }\right)\end{array}$ & $\begin{array}{l}\text { Reservoir } \\
\text { correction } \\
\left({ }^{14} \mathrm{C} \text { yr }\right)\end{array}$ & $\begin{array}{l}\text { Corrected }{ }^{14} \mathrm{C} \text { age } \\
\left({ }^{14} \mathrm{C} \text { yr B.P. }\right)\end{array}$ & $\begin{array}{l}\text { Calibrated age } \\
\text { (cal yr B.P.) } \\
\text { (2-Std.dev.range) }\end{array}$ \\
\hline KIA-10244 & Bivalve & 55 & $2840 \pm 25$ & -440 & 2400 & $2530(2477-2613)$ \\
\hline KIA-10243 & Bivalve & 65 & $3085 \pm 30$ & -440 & 2645 & $2785(2761-2838)$ \\
\hline KIA-10242 & Bivalve & 72 & $3370 \pm 30$ & -440 & 2930 & 3194 (3146-3230) \\
\hline KIA-10241 & Bivalve & 73 & $3540 \pm 30$ & -440 & 3100 & $3371(3346-3401)$ \\
\hline KIA-10240 & Wood & 315 & $12,880 \pm 90$ & no & 12,880 & $15,512(14,993-15,732)$ \\
\hline
\end{tabular}

The $\mathrm{Ob}$ and Yenisei rivers, which, respectively, discharge approximately 400 and $580 \mathrm{~km}^{3}$ of water/yr and provide more than $70 \%$ of the total freshwater runoff, control the freshwater supply to the Kara Sea (Gordeev, 2000; Rachold et al., 2003). Most of this fluvial input occurs during early summer. Although the extent and distribution of the freshwater shelf plumes vary depending on summer winds, riverine waters commonly affect almost half of the total sea area (Burenkov and Vasil'kov, 1995; Pivovarov et al., 2003). The offshore spread of the $\mathrm{Ob}$ and Yenisei waters is clearly reflected by the mean, multiannual pattern of surface-water salinity which gradually decreases away from the river mouths. Salinity ranges from $<5$ in the estuaries to 30 in distant areas of the Kara Sea (Dmitrenko et al., 1999; Fig. 1).

A recurrent polynya in the Kara Sea is one of the major source areas for sea ice in the Siberian branch of the Transpolar Drift (Pfirman et al., 1997; Zakharov, 1996). The polynya generally develops during winter in near-shore regions of the Yamal Peninsula, the outer Ob estuary, and to the north of the Yenisei estuary (Dmitrenko et al., 2000). Our sediment cores were obtained near the present day, mean interannual location of the polynya (Fig. 1).

\section{Sedimentary setting, core site, and stratigraphy}

Modern sedimentation on the inner Kara Sea shelf is strongly affected by the $\mathrm{Ob}$ and Yenisei rivers, which deliver approximately $70 \%$ of the total suspended matter discharged to the Kara Sea $(\mathrm{Ob}: 16.5$ tons/yr; Yenisei: 5.9 tons/yr; Gordeev, 2000). This material is typically mobilized from terraces and floodplains found in the lower reaches of these rivers (Meade et al., 2000). Most of the river load is deposited in the $\mathrm{Ob}$ and Yenisei estuaries and offshore submarine channels that are submerged paleovalleys (Dittmers et al., 2003; Stein, 2001; Stein et al., 2003).

Cores BP99-04 and BP99-05/01 were obtained from the "marginal filter" (Fig. 1) of the Kara Sea (Lisitzin, 1995; Stein, 2001; Stein et al., 2003). This filter is characterized by rapid precipitation of fine-grained, suspended matter. According to echograph profiling and magnetic susceptibility measurements, the cores represent two lithological units (I and II) that are correlated with acoustic units I (with Subunits Ia and Ib) and II (Dittmers et al., 2003; Stein, 2001). Core BP99-04 is composed mainly of clayey silts representing unit I (Ia and Ib), whereas core BP99-05/1, located in the outer part of the marginal filter, penetrates into sediments of Subunits Ia and Ib and the underlying unit II (Fig. 2).

Based on calibration of AMS ${ }^{14} \mathrm{C}$ dates (Table 1; Figs. 2 and 3), core BP99-04/7 encompasses the last $\sim 10,000 \mathrm{cal} \mathrm{yr}$ B.P. AMS ${ }^{14} \mathrm{C}$ dates of samples from core BP9905/1 indicate that sandy unit II is of pre-Holocene, postglacial age (approximately 15,500 cal yr B.P.), and that the lower part of Subunit Ia is probably missing (for details, see Stein et al., 2003).

\section{Results}

\section{Core BP99-04/7}

Diatom assemblages are taxonomically diverse (approximately 270 species and varieties) and abundant (0.02- 


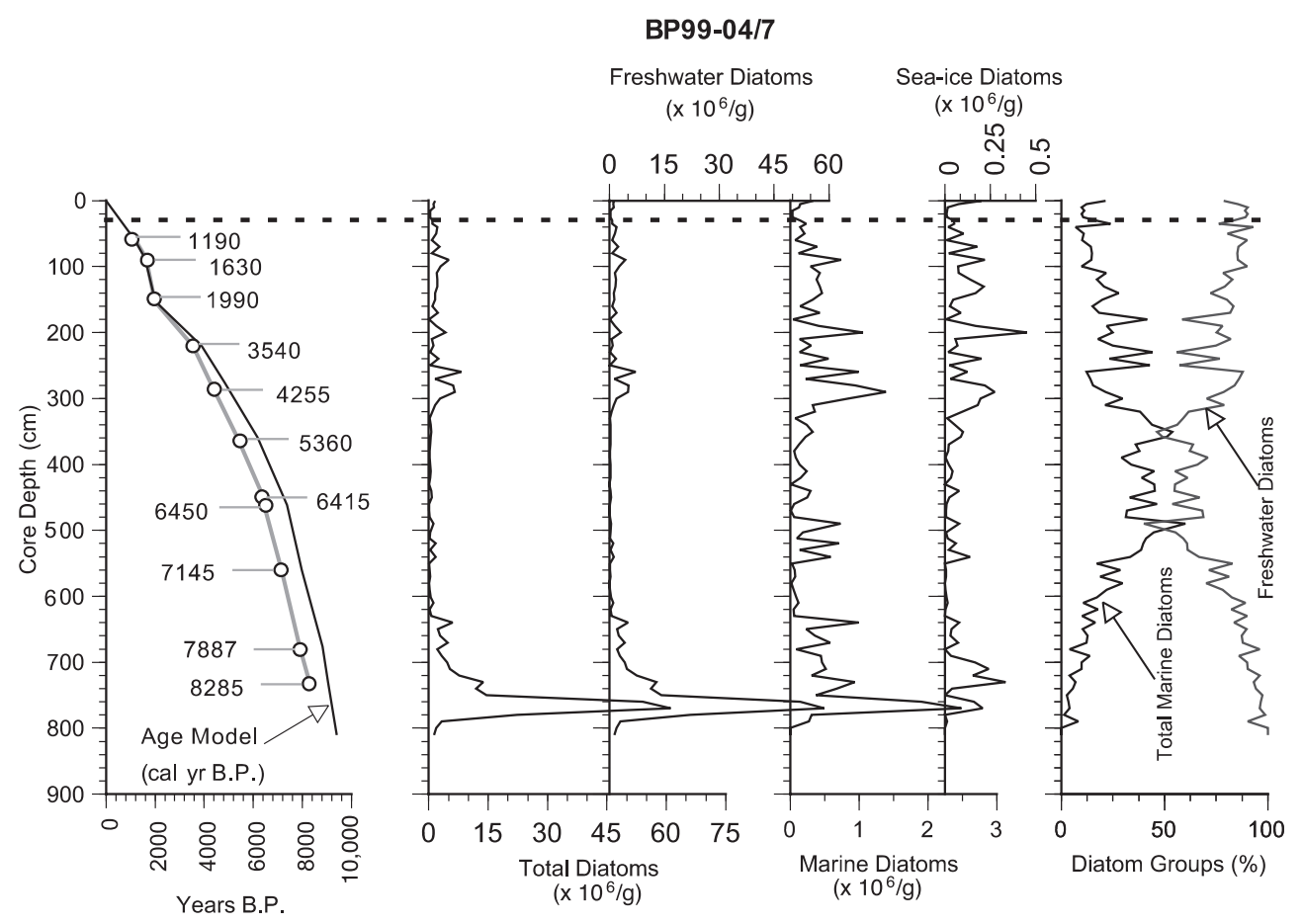

Figure 3. Radiocarbon dates (see Table 1), derived cal yr B.P. age model (black line), and abundances and percentages of the main ecological diatom groups (note the different horizontal scales) for core BP99-04/7. Data points from above the hatched line represent samples taken from the multicorer (MUC) core BP99-04/5.

$61.2 \times 10^{6}$ valves/g dry sediment). The total concentration of diatom valves is variable (Fig. 3). Maximum abundances (up to $61.2 \times 10^{6}$ valves $/ g$ dry sediment) occur between 750 and $780 \mathrm{~cm}$ and consist mainly of freshwater diatoms (up to $98.9 \%$ ) dominated by riverine planktonic species. The lowest concentrations of diatoms, which average $0.5 \times 10^{6}$ valves/g dry sediment, appear between 330 and $630 \mathrm{~cm}$ and correspond to an interval with the highest percentages of marine diatoms (average approximately $40 \%$ ). The upper $300 \mathrm{~cm}$ of the core is marked by a steep increase in diatom concentrations (average $2.3 \times$ $10^{6}$ valves/g dry sediment). Relative abundances of freshwater diatoms tend to increase in this period.

Diatom species were combined into two main ecological groups: freshwater diatoms, and marine and brackish-marine diatoms. The freshwater diatoms are represented by riverine and boggy taxa transported by rivers to the shelf zone. Their relative abundances in the diatom assemblages vary between $40 \%$ and $100 \%$, with a substantial number of samples being well above $70 \%$ (Fig. 3), indicating a constant riverine supply to the study area. Riverine planktonic species dominated by Aulacoseira islandica, A. italica, A. subarctica, A. granulata, and Asterionella formosa are the most important freshwater taxa, and their total percentages range from $12 \%$ to $80 \%$. The good correlation between percentages of freshwater diatoms in surface-sediment assemblages from the Kara Sea shelf and the distributional pattern of summer surface-water salinity (Fig. 1) indicates that this group of diatoms can be used to infer fluctuations in paleosalinity (Polyakova, 2003). A linear regression between average summer surface-water salinity and relative proportions of freshwater diatoms reveals a correlation coefficient of $r=0.86$ for a salinity range of approximately 5 to 20 .

The group of marine and brackish-marine diatoms (Fig. 3) consists largely (up to 20\%) of euryhaline species (Thalassiosira baltica, T. hyperborea, Melosira juergensii, M. moniliformis) typical of freshened areas of the Arctic shelf (Polyakova, 1994, 1997). The marine diatoms also include a specific group of sea-ice species dominated by Fossula arctica, Fragilariopsis oceanica, and F. cylindrus, indicating the presence of sea ice in the Eurasian arctic seas (Polyakova, 1997; Cremer, 1999a,b). A steep increase $(>10-20 \%)$ in relative abundances of sea-ice diatoms corresponds to the mean interannual position of the winter polynya (Bauch and Polyakova, 2000; Polyakova, 2003; Polyakova et al., 2000). Although the relative abundances of sea-ice species vary between $0 \%$ and $16 \%$, they mainly are $<10 \%$ (Fig. 3), thus indicating a generally more distal and seaward location of the polynya. Other marine diatoms are represented mainly by cold-water, arctic-boreal, and bipolar planktonic types (e.g., Thalassiosira antarctica, T. gravida, T. nordenskioeldii, Chaetoceros diadema, C. mitra) and by benthic taxa (e.g., Diploneis smithii, D. interrupta, Trachineis aspera) that are common in arctic seas.

In Subunit Ib of core BP99-04/7, TOC is $<1.2 \%$ (Fig. 4). With the change to silty-clayey Subunit Ia, TOC sharply increases to almost $2 \%$. Between 100 and $675 \mathrm{~cm}$ (approximately 2000 to $9000 \mathrm{cal}$ yr B.P.), TOC varies between $0.8 \%$ and $1.6 \%$, with minimum values between 110 and $480 \mathrm{~cm}$. In the upper $100 \mathrm{~cm}$ (i.e., during the last 2000 


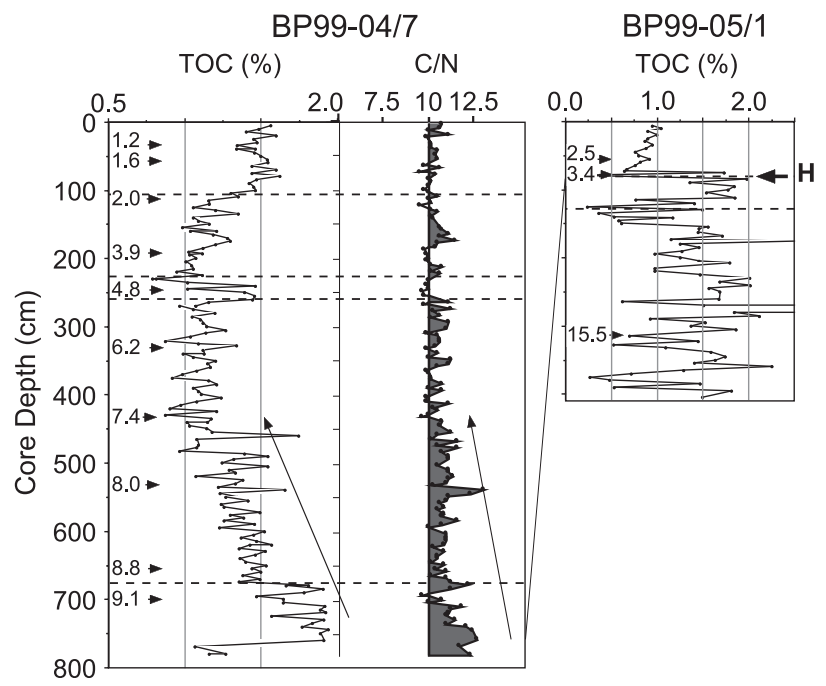

Figure 4. Radiocarbon dates (see Total organic carbon (TOC) content of cores BP99-04/7 and BP99-05/1. For Core BP99-04/07, the C/N ratios are also shown. Numbers next to black arrows are cal ages, $\times 10^{3}$ (see Stein et al., 2003). H indicates hiatus.

cal yr B.P.), samples with TOC of approximately $1.5 \%$ are typical (Fig. 4). Most of the $\mathrm{C} / \mathrm{N}$ ratios are $>10$, with maximum values in the lower part of the sequence where terrigenous organic matter dominates. The prevalence of terrigenous organic matter is also supported by the hydrogen index and the high concentrations of long-chain $n$-alkanes (Stein and Fahl, 2003; Stein et al., 2003).

\section{Core BP99-05/01}

The approximately 210 species and varieties of diatoms recognized in core BP99-05/01 represent mainly freshwater taxa (approximately 90\%). Total concentrations of diatom valves are variable throughout the core (from 0.04 to $9.4 \times$ $10^{6}$ valves/g dry sediment; Fig. 5). Marine and brackish- marine diatoms are recorded only in the upper $140 \mathrm{~cm}$ of the core and mainly represent euryhaline species (Thalassiosira baltica, T. hyperborea, Melosira jurgensii). However, coldwater planktonic and sea-ice types (Thalassiosira antarctica, T. gravida, Fossula arctica, Fragilariopsis oceanica, F. cylindrus, Bacterosira bathyomphala) are also present. Only single valves occur between 70 and $140 \mathrm{~cm}$, and maximum relative abundances (up to $11.5 \%$ ) are observed in the upper $70 \mathrm{~cm}$ of the core. Freshwater diatom assemblages are largely comprised of riverine planktonic species (up to $67.1 \%$, average $44.6 \%$; Fig. 5) with a predominance of Aulacoseira species (A. italica, A. granulata, A. distans).

Between 140 and $405 \mathrm{~cm}$, only freshwater diatoms occur. The assemblage is dominated by riverine planktonic diatoms. Other commonly encountered diatoms include the taxonomically diverse, small, benthic species of Fragilaria, Eunotia, and Gomphonema (F. construens, F. pinnata, G. acuminatum, G. parvulum, E. lunaris, E. pectinalis), which today occupy depressions in flooded surfaces of the lower Yenisei River. Essential components of these assemblages are rheophilic species (e.g., Didymosphenia geminata, Meridion circulare) that inhabit flowing waters and aerophilic species (e.g., Luticola mutica, Hantzschia amphioxys) that are frequently reported in subaerial and dry habitats (Campeau et al., 1999). Such a heterogeneous composition of diatom assemblages is typical for low-lying lands episodically covered by river waters during spring and early summer floods (Polyakova, unpublished data). A general decrease in the percentages of planktonic species and an increase in the quantitative abundance of diatom valves (mainly Fragilaria species) occur between 210 and $400 \mathrm{~cm}$. This trend indicates possible temporal changes in riverine sedimentation at the study site.

In core BP99-05/01, TOC below $130 \mathrm{~cm}$ displays highamplitude variations between $0.2 \%$ and $2.5 \%$ (Fig. 4). In a peat horizon of a few centimeter thickness, a maximum

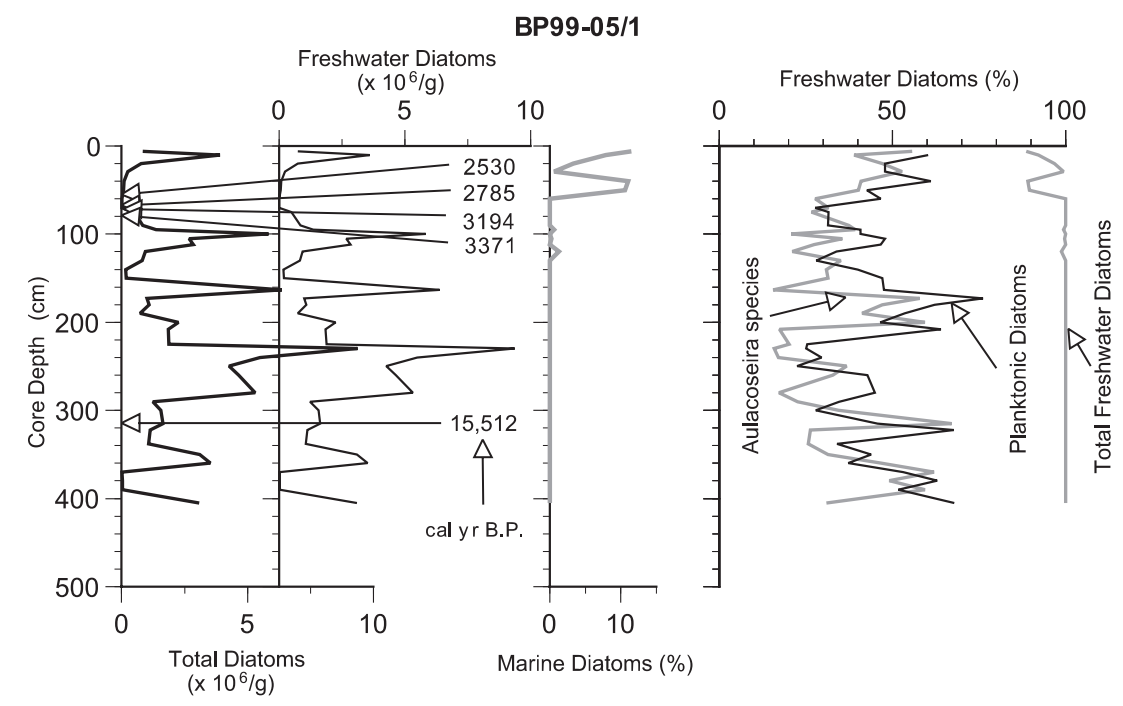

Figure 5. Diatom valve concentrations and percentages of the major diatom groups in core BP99-05/1. Calibrated ages (see Table 1) are also indicated. 
TOC of $11.9 \%$ was measured near $275 \mathrm{~cm}$. In the overlying laminated subunit, high TOC (approximately $1.7 \%$ ) dominates. In the upper $70 \mathrm{~cm}$ of silty clay (i.e., during the last $\sim 3000 \mathrm{cal}$ yr B.P.), TOC is between $0.6 \%$ and $1 \%$.

\section{Hydrological and depositional environments over the last} 15,500 cal $y r$

The environment of the Kara Sea shelf is strongly influenced by a huge riverine discharge, primarily from the $\mathrm{Ob}$ and Yenisei rivers. Intermixing of fresh and marine waters determines the major spatial characteristics of the hydrological and sedimentation processes on the present day, inner shelf of the Kara Sea. During postglacial times, the shallow arctic shelves were dramatically affected by rising sea levels that stabilized by $5000 \mathrm{cal}$ yr B.P. (Bauch et al., 1999, 2001b; Kaplin, 1973; Stein and Fahl, 2000, 2003). The southward retreat of the coastline had a profound influence on depositional environments of the shelf (Dittmers et al., 2003; Stein et al., 2003).

The study sites, BP99-04 and BP99-05/1, currently are situated in the northern position of the marginal filter that underlies the Yenisei River discharge (Fig. 2). Diatom records from lithological unit II of core BP99-05/1 indicate the presence of riverine and boggy depositional environments within the flooded lowlands approximately 15,500 cal yr B.P. (Fig. 5). Because this core was taken from a water depth of $38.5 \mathrm{~m}$, we assume that, during the late glaciation, sea level in the Kara Sea was more than $40 \mathrm{~m}$ below its present position.

With higher sea levels, the shoreline migrated landwards causing a retreat of the Yenisei River mouth. Diatom assemblages from lithological unit I in both cores indicate the development of brackish water conditions. This change of depositional environment is marked by the first occurrence of marine diatoms in core BP99-05/1 (Subunit Ib; Figs. 2 and 5). Additional evidence for a change in hydrology and sedimentation approximately 9100-9300 cal yr B.P. is recorded near the base of core BP99-04 (Subunit Ib; Figs. 2 and 3). Diatom assemblages from this part of the core are characterized by maximum concentrations (up to $61.2 \times 10^{6}$ valves/g dry sediment) and percentages of the freshwater group (>90\%). Comparable concentrations of diatom valves are observed in surface sediments of the outer $\mathrm{Ob}$ and Yenisei estuaries, which also are dominated by freshwater groups (92-98\%; Fig. 1, Polyakova, 2003). This zone of intermixing of fresh and sea waters (sea-surface salinity between 2 and 7) is characterized by an "avalanche-like" precipitation of riverloaded organic matter, consisting primarily of planktonic diatoms, which is caused by coagulation and flocculation (Lisitzin, 1995, 2002). Thus, extremely high accumulation rates of diatom valves and maximum accumulation rates of total sediment and TOC (Figs. 6a and 7) in core BP99-04 prove that the Yenisei River mouth was located close to the study site between 9100 and 9300 cal yr B.P. This interpretation is supported by the absence of marine diatoms (Fig. 3) and any other marine organisms (Kraus et al., 2003) in the underlying sediments ( $>9300 \mathrm{cal}$ yr B.P.). Diatom assemblages from the lowermost part of the core are comprised mainly of riverine planktonic species of Aulacoseira (up to $80 \%$ ) and indicate fluvial depositional environments during a time of lowered $(<38-40 \mathrm{~m})$ sea levels. Stable oxygen isotope and micropalaeontological data from

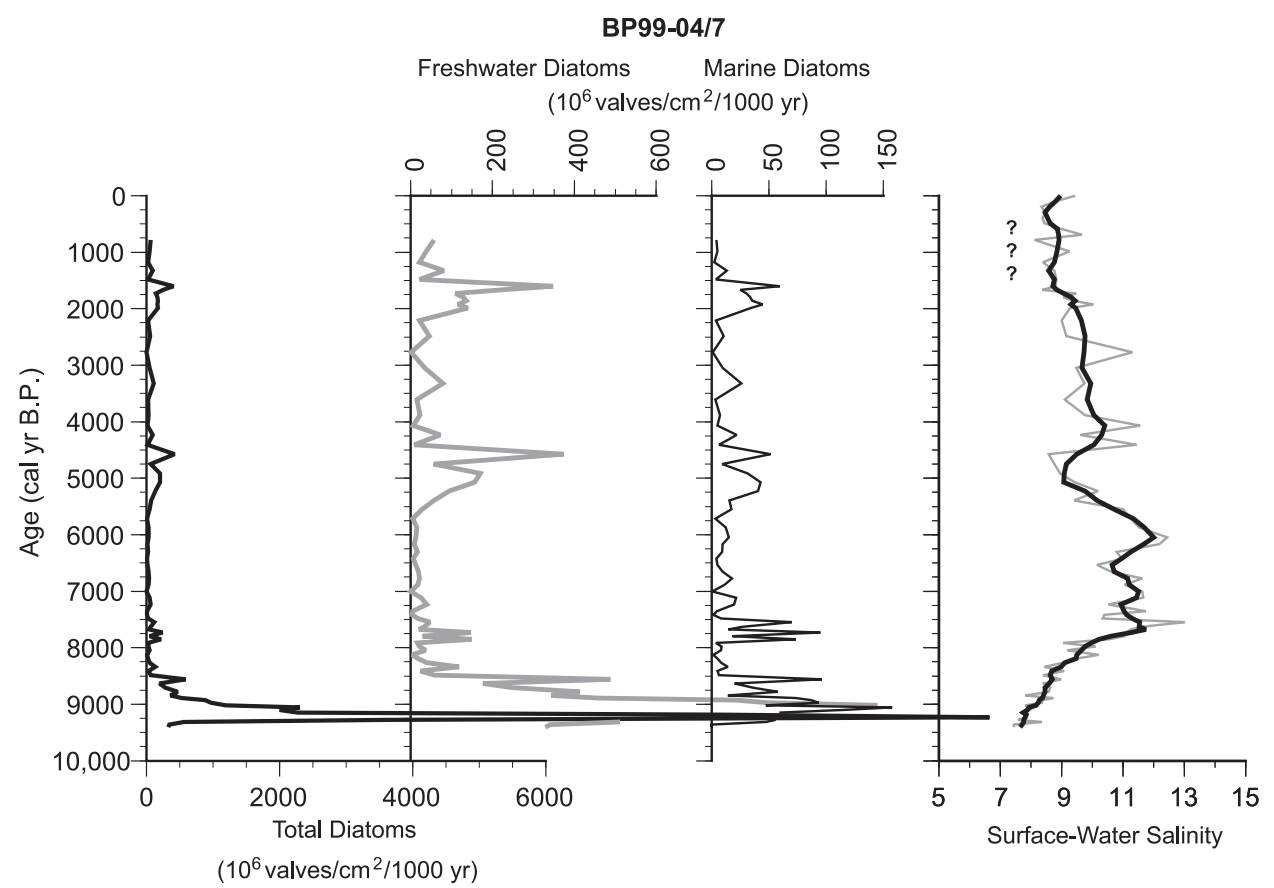

Figure 6. Accumulation rates of total diatom valves, freshwater taxa, and marine taxa; and reconstructed surface-water salinities. 
a sediment core located approximately $60 \mathrm{~km}$ north of core BP99-04 (Polyak et al., 2002) also suggest a strong riverine influence until approximately 9000 cal yr B.P. caused by lowered sea level. A similar estuarine system and depositional environment have been described for the early Holocene (9000 and 8600 cal yr B.P.) in the southeastern Laptev Sea from a sediment core taken from a paleowater depth $(32 \mathrm{~m})$ similar to that of the Kara Sea cores (Bauch and Polyakova, 2003).

A further landward migration of the river depocenter can be inferred from changes in the composition of diatom assemblages and accumulation rates of total sediment and organic carbon in Subunit Ia of both cores. Percentages of marine diatoms in sediment assemblages (up to $11.5 \%$ ) from the upper part of core BP99-05/1 (<3400 cal yr B.P.; Fig. 5) indicate near-estuarine conditions (Polyakova, 2003). The gradual transition from estuarine to brackishmarine conditions caused by rising sea levels and temporal variations in riverine discharge are recorded in detail for the past $9100 \mathrm{cal}$ yr B.P. in core BP99-04 (Figs. 3, 6, and 7). A sharp decrease in the accumulation rates of diatom valves and the gradual decline in accumulation rates of total sediment and organic carbon indicate a landward migration of the center of the marginal filter. Changes in freshwater diatoms suggest that, from 9100 to 8500 cal yr B.P., surface-water salinity increased up to 8.5-9.0 at the study site (Fig. 6).

Salinity increased to $12-13$ by 7500 cal yr B.P., indicating the presence of marine conditions and consequent environmental changes associated with the southward migration of the coast to the core site. Sea level in the shallow Eurasian arctic seas was already close to its modern position by approximately 7500 cal yr B.P. (Bauch et al., 1999, 2001a,b; Stein et al., 2003, 2004). Thus, the diatom records for the past $9300-7500$ cal yr B.P. from the southeastern Kara Sea shelf primarily reflect the history of river-mouth retreat southward, away from the core site,

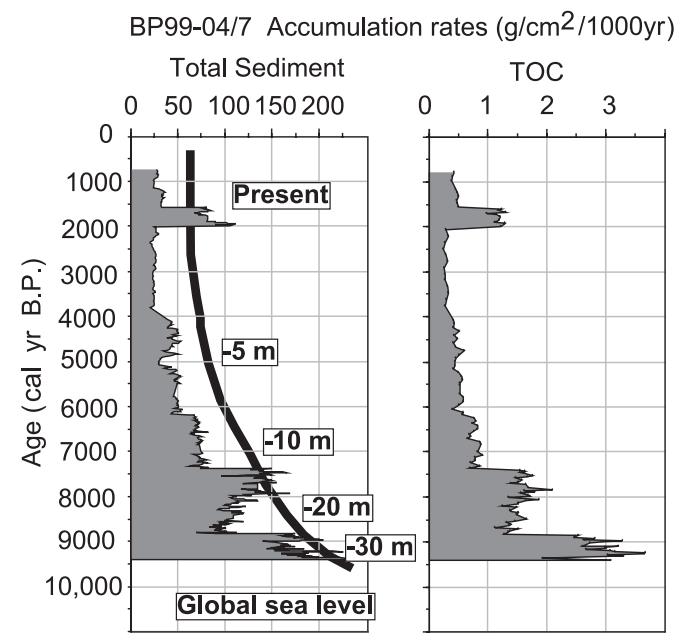

Figure 7. Accumulation rates of total sediment and total organic carbon (TOC). The global sea-level curve is from Fairbanks (1989).
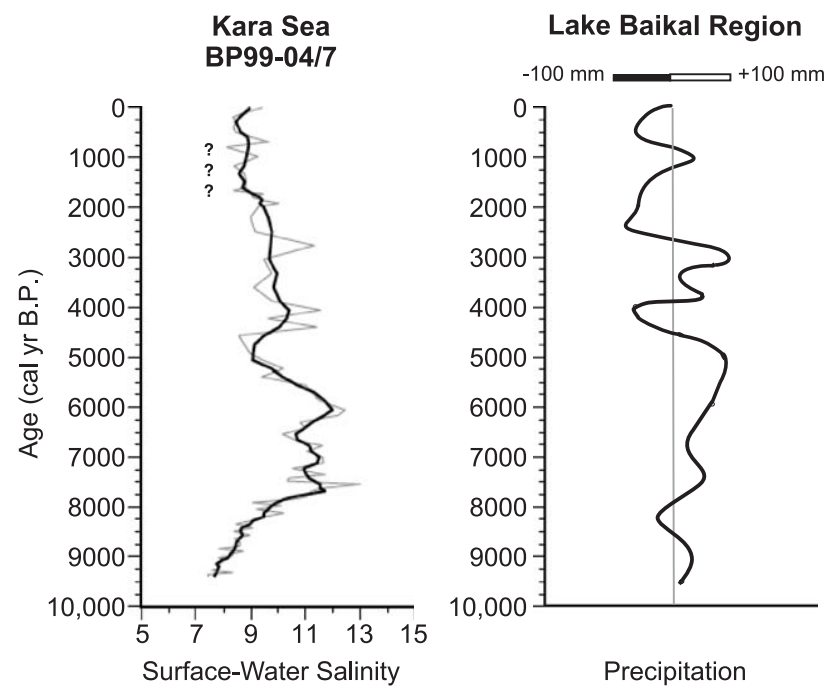

Figure 8. Comparison of the reconstructed surface-water salinity in the southeastern Kara Sea from core BP99-04/7 and precipitation changes in the Lake Baikal region (after Vorobyeva, 1994) during the past 10,000 cal yr B.P.

resulting in rising paleosalinities. This scenario is in good agreement with the stepwise decrease in diatom accumulation rates, total sediment, and TOC (Figs. 6 and 7) that is evident today along the outer part of the marginal filter of the Kara Sea (Lisitzin, 1995, 2002). Superimposed on the general decrease in diatom accumulation rates is an interval of maximum rates between 7500 and 8000 cal yr B.P. (Figs. 6 and 7). Relatively high accumulation rates of marine diatoms indicate an increase in productivity of both planktonic and sea-ice communities. This maximum coincides with the northernmost expansion of the boreal forest to the arctic coast, a time characterized by Siberian climates that were warmer and wetter than present (e.g., Andreev and Klimanov, 2000; Andreev et al., 2002; MacDonald et al., 2000; Wolfe et al., 2000). Such conditions probably resulted in high Yenisei River runoff rates (Stein et al., 2003). The rise in accumulation rates of riverine freshwater diatoms (Fig. 6) suggests that the high marine-productivity event may be due to an increase in nutrient supply to the inner Kara Sea shelf.

Between 7500 and $6000 \mathrm{cal}$ yr B.P., paleosalinities were well above modern levels (up to 12-13). This period encompasses an interval of enhanced Atlantic water inflow to the Franz Victoria and St. Anna troughs of the northwestern Kara Sea, with maximum inflow occurring approximately $7000 \mathrm{cal}$ yr B.P. (Lubinski et al., 2001). Given the modern distributional pattern of Atlantic waters in the Kara Sea (Dmitrenko et al., 1999; Hanzlick and Aagaard, 1980; Karcher et al., 2003) and the documented eastward incursion of Atlantic waters during the mid-Holocene, the unusual paleosalinity values within the southeastern Kara Sea likely were caused by the influx of Atlantic waters that perhaps entered this region through submerged paleoriver channels. 
From approximately 6000 cal yr B.P. to present, paleosalinity gradually decreased to the modern level. Two major phases (approximately 5000 and $2000 \mathrm{cal} \mathrm{yr} \mathrm{B.P.)} \mathrm{of}$ relatively low paleosalinities (approximately 8-9; Fig. 6) coincided with increasing diatom accumulation rates, probably indicating relatively high productivity of riverine plankton or increase in riverine discharge. The later phase (approximately 1800-2000 cal yr B.P.) was accompanied by a notable increase in accumulation rates of total sediments and TOC (Stein et al., 2003; Fig. 7) that provide evidence for increase in riverine supply during this interval. Since 1800 cal yr B.P., surface-water salinity has varied between 8 and 10. This period is also marked by a pronounced decrease in diatom accumulation rates, mainly of marine species, and in TOC, suggesting low sea-water productivity (Figs. 6 and 7). Particle-size analysis and magnetic susceptibility indicate that the Yenisei River discharge/ current velocity lessened during the last $\sim 2500 \mathrm{cal}$ yr (Stein et al., 2003, 2004). This decrease seems to correlate with a decline in precipitation in the Lake Baikal region (Fig. 8), which via the Angara River is one of the major water sources to the Yensei River (see below). This trend is likely related to "sub-Atlantic cooling" in sub-Arctic regions and the development of modern vegetation zones in coastal and near coastal areas of the Kara Sea (e.g., Andreev and Klimanov, 2000; Hahne and Melles, 1999; Kraus et al., 2003; Velichko et al., 1997). Thus, the relatively low abundances of marine diatoms may have been caused by decreased productivity of marine diatom biocoenoses.

Sedimentological proxies indicate that a reduction in Yenisei discharge occurred over the last 2000 cal yr B.P (Stein et al., 2003, 2004). However, the diatom record shows a decrease in salinity, suggesting an increase in discharge. This discrepancy may relate to the greater effectiveness of the marginal filter as a sediment trap, implied by the greater accumulation of fine-grained, TOCrich materials (Stein et al., 2003, 2004). In the same way, the amount of freshwater diatoms accumulating in the estuary may have increased at this time without a necessary increase in absolute discharge. Thus, absolute paleosalinity values should be interpreted with caution.

Past centennial to millennial scale variability in riverine discharge from the vast Yenisei drainage basin ultimately results from paleoclimatic fluctuations in the continental interior. Moreover, the inflow of the modern Angara River, which comprises $>20 \%$ of the total annual water discharge of the Yenisei River (Meade et al., 2000), is of key importance for understanding the history of riverine inflow to the Kara Sea shelf. The discharge of the Angara River (the major tributary of the Yenisei River), having Lake Baikal as its source, is controlled by the hydrological regime of this great Eurasian basin. The available data indicate that variations in Holocene hydrological environments at Lake Baikal can be linked to shifts in regional climatic patterns (Bradbury et al., 1994; Karabanov et al., 2000). However, the Yenisei River discharge inferred from diatom assemb- lages partly displays an opposite trend to the precipitation record from the Lake Baikal region (Fig. 8; Bezrukova, 1999; Bezrukova et al., 2002; Vorobyeva, 1994). Diatom salinity records are controlled by changes in river discharge, sea level, and the effectiveness of the marginal filter as a sediment trap. All these factors must be considered when inferring past trends, and they are likely responsible for the partial discrepancy between the above precipitation and discharge trends.

The relative abundances of sea-ice diatoms within the total marine diatom group steeply increase above $10-20 \%$ in surface-sediment samples seaward of the mean interannual location of the winter polynya (Polyakova, 2003). Because such abundances remained $<10 \%$ (average $<2 \%$ ) between 9100 and 7900 cal yr B.P. (Fig. 3), the study area must have been located beyond the influence of pack ice. Since 7500 cal yr B.P., the polynya was close to its modern location, with a short time of landward migration between 6400 and $5200 \mathrm{cal} \mathrm{yr}$ B.P.

\section{Acknowledgments}

This study has been performed within the joint GermanRussian multidisciplinary research project on "Siberian River Run-off (SIRRO)." We thank M. Pirrung and M. Kraus for measuring the magnetic susceptibility of cores BP99-04/7 and BP99-05/1. We also wish to thank H. Bauch and J. Simstich for their fruitful comments and constructive discussions during the preparation of this manuscript. I. Dmitrenko and S. Berezovskaya kindly made available data on water salinities and sea-ice conditions in the Kara Sea. Review and editorial comments by L. Burckle, P. M. Anderson, and one anonymous reviewer are gratefully acknowledged. This research was supported by the German Ministry of Education, Science, Research and Technology (BMBF) (grant no. 03G0547A) and the Russian Foundation of Basic Research (RFBR) (Grant no. 03-05-65018).

\section{References}

Aagaard, K., Carmack, E.C., 1989. The role of sea ice and other fresh water in the Arctic circulation. Journal of Geophysical Research 94, $485-498$.

Aibulatov, N.A. (Ed.), Geoecology of Shelf and Coasts of Russian Seas. Noosphera, Moscow.

Andreev, A.A., Klimanov, V.A., 2000. Quantitative Holocene climatic reconstruction from Arctic Russia. Journal of Paleolimnology 24, 81-91.

Andreev, A.A., Siegert, C., Klimanov, V.A., Derevyagin, A.Yu., Shilova, G.N., Melles, M., 2002. Late Pleistocene and Holocene vegetation and climate on the Taymyr Lowland, Northern Siberia. Quaternary Research 57, $138-150$.

Battarbee, R.W., 1973. A new method for estimation of absolute microfossil numbers, with reference especially to diatoms. Limnology and Oceanography 18, 647-654.

Bauch, H.A., Polyakova, Ye.I., 2000. Late Holocene variations in Arctic shelf hydrology and sea-ice regime: evidence from north of the Lena Delta. International Journal of Earth Science 89, 569-577. 
Bauch, H.A., Polyakova, Ye.I., 2003. Diatom-inferred salinity records from the Arctic Siberian margin: implications for fluvial runoff patterns during the Holocene. Paleoceanography 18, 5.1-5.10.

Bauch, H.A., Kassens, H., Erlenkeuser, H., Grootes, P.M., Thiede, J., 1999. Depositional environment of the Laptev Sea shelf (Arctic Siberia) during the Holocene. Boreas 28, 194-204.

Bauch, H.A., Kassens, H., Kunz-Pirrung, M., Naidina, O., Thiede, J., 2001a. Composition and flux of Holocene sediments on the eastern Laptev Sea shelf, Arctic Siberia. Quaternary Research 55, 344-351.

Bauch, H.A., Mueller-Lupp, T., Taldenkova, E., Spielhagen, R.F., Kassens, H., Grootes, P.M., Thiede, J., Heinemeier, J., Petryashov, V.V., $2001 \mathrm{~b}$. Chronology of the Holocene transgression at the North Siberian margin. Global and Planetary Change 31, 125-139.

Bezrukova, E.V., 1999. Palaeogeography of Baikal Region During the Late Pleistocene and Holocene. Nauka, Novosibirsk. In Russian.

Bezrukova, Ye.V., Abzaeva, A.A., Vershinina, K.E., Krapivina, S.M., 2002. History of distribution of forests on the eastern coast of Lake Baikal during the Late Pleistocene and Holocene. Geography: Natural Resources 3, 68-74 (In Russian)

Bradbury, P., Bezrukova, Ye.V., Chernyaeva, G.P., Colman, S.M., Khursevich, G., King, J.W., Likhoshway, Ye.V., 1994. A synthesis of post-glacial diatom records from Lake Baikal. Journal of Paleolimnology $10,213-252$.

Burenkov, V.I., Vasil'kov, A.P., 1995. The influence of runoff from land on the distribution of hydrologic characteristics of the Kara Sea. Oceanology 34 (5), 591-599 (English translation).

Campeau, S., Pienitz, R., Hequette, A., 1999. Diatoms from the Beaufort Sea coast, southern Arctic Ocean (Canada). Modern analogues for reconstructing Late Quaternary environments and relative sea levels. Bibliotheca Diatomologica Band 41, 1-244.

Cremer, H., 1999a. Distribution patterns of diatom surface sediment assemblages in the Laptev Sea (Arctic Ocean). Marine Micropalaeontology $38,39-67$.

Cremer, H., 1999b. Spatial distribution of diatom surface sediment assemblages on the Laptev Sea shelf. In: Kassens, H., Bauch, H.A., Dmitrenko, I., Eicken, H., Hubberten, H.W., Melles, M., Thiede, J., Timokhov, L. (Eds.), Land-Ocean System in the Siberian Arctic. Dynamics and History. Springer-Verlag, New York, pp. 533-560.

Dittmers, K., Niessen, F., Stein, R., 2003. Holocene sediment budget and sedimentary history for the $\mathrm{Ob}$ and Yenisei estuaries. In: Stein, R., Fahl, K., Fütterer, D.K., Galimov, E.M., Stepanets, O.V. (Eds.), Siberian River Run-off in the Kara Sea: Characterization, Quantification, Variability, and Environmental Significance, Proceedings in Marine Sciences, vol. 6. Elsevier, Amsterdam, pp. 457-478.

Dmitrenko, I.A., Gribanov, V.A., Volkov, D.L., Kassens, H., 1999. Impact of river discharge on the sea land fast ice extension in the Russian arctic shelf area. In: Tuhkuri, J., Riska, K. (Eds.), Proceedings of 15th International Conference on Port and Ocean Engineering Under Arctic Conditions, Helsinki University of Technology, Espoo, Finland, August 23-27, pp. $311-321$.

Dmitrenko, I.A., Gribanov, V.A., Volkov, D.L., Berezovskaya, S.L., Kassens, H., 2000. The role of riverine runoff in the interannual variability of the fast ice distribution in the Russian Arctic. Meteorology and Hydrology 3, 85-94 (In Russian).

Fahl, K., Stein, R., 1997. Modern organic-carbon-deposition in the Laptev Sea and the adjacent continental slope: surface-water productivity vs. terrigenous input. Organic Geochemistry 26, 379-390.

Fahl, K., Stein, R., 1999. Biomarkers as organic-carbon-source and environmental indicators in the Late Quaternary Arctic Ocean: problems and perspectives. Marine Chemistry 63, 293-309.

Fairbanks, R.G., 1989. A 17,000-year glacio-eustatic sea level record: influence of glacial melting rates on the Younger Dryas event and deep ocean circulation. Nature $342,637-642$.

Gordeev, V.V., 2000. River input of water, sediment, major ions, nutrients and trace metals from Russian territory to the Arctic Ocean. In: Lewis, E.L., Jones, E.P., Lemke, P., Prowse, T.D., Wadhams, P. (Eds.), The Freshwater Budget of the Arctic Ocean. Kluwer, Netherlands, pp. 297-322.
Hahne, J., Melles, M., 1999. Climate and vegetation history of the Taymyr Peninsula since Middle Weichselian time-Palynological evidence from Lake sediments. In: Kassens, H., Bauch, H.A., Dmitrenko, I., Eicken, H., Hubberten, H.W., Melles, M., Thiede, J., Timokhov, L. (Eds.), Land-Ocean System in the Siberian Arctic. Dynamics and History. Springer-Verlag, New York, pp. 407-423.

Hanzlick, D., Aagaard, K., 1980. Freshwater and Atlantic water in the Kara Sea. Journal of Geophysical Research 85, 4937-4942.

Kaplin, P.A., 1973. Nearest History of the World Ocean Coasts. MSU Publisher House, Moscow. In Russian.

Karabanov, E.E., Prokopenko, E., Williams, D., Khursevich, G.K., 2000. A new record of Holocene climate change from bottom sediments of Lake Baikal. Palaeogeography, Palaeoclimatology, Palaeoecology 156, 211-224.

Karcher, M.J., Kulakov, M., Pivovarov, S., Schauer, U., Kauker, F., Schlitzer, R., 2003. Atlantic water flow to the Kara Sea: comparing model results with observations. In: Stein, R., Fahl, K., Fütterer, D.K., Galimov, E.M., Stepanets, O.V. (Eds.), Siberian River Run-off in the Kara Sea: Characterization, Quantification, Variability, and Environmental Significance, Proceedings in Marine Sciences, vol. 6. Elsevier, Amsterdam, pp. 47-72.

Kleiber, H.-P., Niessen, F., 2000. Variations of continental discharge pattern in space and time: implications from the Laptev Sea continental margin, Arctic Siberia. International Journal of Earth Science 89, 605-616.

Kraus, M., Matthiessen, J., Stein, R., 2003. A Holocene marine pollen record from the northern Yenisei estuary (southeastern Kara Sea, Siberia). In: Stein, R., Fahl, K., Fütterer, D.K., Galimov, E.M., Stepanets, O.V. (Eds.), Siberian River Run-off in the Kara Sea: Characterization, Quantification, Variability, and Environmental Significance, Proceedings in Marine Sciences, vol. 6. Elsevier, Amsterdam, pp. $435-456$.

Lisitzin, A.P., 1995. Marginal filter in the oceans. Oceanology 34, 671-682 (English translation)

Lisitzin, A.P., 2002. Sea-ice and Iceberg Sedimentation in the Ocean. Recent and Past. Springer-Verlag, Berlin-Heidelberg.

Lisitzin, A.P., Vinogradov, M.E., 1995. International high-latitude expedition in the Kara Sea (the 49th cruise of the R/V Dmitriy Mendeleev). Oceanology 34, 583-590 (English translation).

Lisitzin, A.P., Shevchenko, V.P., Vinogradov, M.E., Severina, O.V., Vavilova, V.V., 1995. Particle fluxes in the Kara Sea and Ob and Yenisey estuaries. Oceanology 34, 683-693 (English translation).

Lubinski, D.J., Polyak, L., Forman, S.L., 2001. Freshwater and Atlantic water inflows to the deep northern Barents and Kara seas since ca 13 ${ }^{14} \mathrm{C}$ ka: foraminifera and stable isotopes. Quaternary Science Reviews 20, 1851-1879.

MacDonald, G.M, Velichko, A.A., Kremenetski, C.V., Borisova, O.K., Goleva, A.A., Andreev, A.A., Cwynar, L.C., Riding, R.T., Forman, S.L., Edwards, T.W.D., Aravena, R., Hammarlund, D., Szeicz, J.M., Gattaulin, V.N., 2000. Holocene treeline history and climate change across northern Eurasia. Quaternary Research 53, 302-311.

Makarevich, P.R., Druzhkov, N.V., Larionov, V.V., Druzhkova, E.I., 2003. The freshwater phytoplankton biomass and its role in the formation of a high productive zone on the Ob-Yenisei shallows (southern Kara Sea). In: Stein, R., Fahl, K., Fütterer, D.K., Galimov, E.M., Stepanets, O.V. (Eds.), Siberian River Run-off in the Kara Sea: Characterization, Quantification, Variability, and Environmental Significance, Proceedings in Marine Sciences, vol. 6. Elsevier, Amsterdam, pp. $185-193$.

Mangerud, J., Gulliksen, S., 1975. Apparent radiocarbon ages of recent marine shells from Norway, Spitsbergen, and Arctic Canada. Quaternary Research 5, 273-296.

Matthiessen, J., Kraus, M., 2001. Distribution of aquatic palynomorphs along the salinity gradient in the Kara Sea. Reports on Polar Research $393,107-109$.

Matthiessen, J., Kunz-Pirrung, M., Mudie, P.J., 2000. Freshwater chlorophycean algae in recent marine sediments of the Beaufort, Laptev and 
Kara Seas (Arctic Ocean) as indicators of river runoff. International Journal of Earth Science 89, 470-485.

Meade, R.H, Bobrobitskaya, N.N., Babkin, V.I., 2000. Suspended-sediment and fresh-water discharges in the $\mathrm{Ob}$ and Yenisei rivers, 1960-1988. International Journal of Earth Science 89, 461-469.

Nöthig, E.-M., Okolodkov, Y., Larionov, V.V., Makarevich, P.R., 2003. Phytoplankton distribution in the Kara Sea: a composition of three summer investigations. In: Stein, R., Fahl, K., Fütterer, D.K., Galimov, E.M., Stepanets, O.V. (Eds.), Siberian River Run-off in the Kara Sea: Characterization, Quantification, Variability, and Environmental Significance, Proceedings in Marine Sciences, vol. 6. Elsevier, Amsterdam, pp. $163-183$.

Pavlidis, Yu.A., Ionin, A.S., Scherbakov, F.A., Dunaev, N.N., Nikiforov, S.L., 1998. Arctic Shelf. Late Quaternary History as a Predicting Base of Future Changing. GEOS, Moscow.

Pfirman, S.L., Colony, R., Nürnberg, D., Eiken, H., Rigor, I., 1997. Reconstructing the origin and trajectory of drifting Arctic sea ice. Journal of Geophysical Research 102, 12.575-12.586.

Pivovarov, S.V., Schlitzer, R., Novikhin, A., 2003. River run-off influence on the water mass formation in the Kara Sea. In: Stein, R., Fahl, K., Fütterer, D.K., Galimov, E.M., Stepanets, O.V. (Eds.), Siberian River Run-off in the Kara Sea: Characterization, Quantification, Variability, and Environmental Significance, Proceedings in Marine Sciences, vol. 6. Elsevier, Amsterdam, pp. 9-26.

Polyak, L., Levitan, M., Khusid, T., Merklin, L., Mukhina, V., 2002. Variations in the influence of riverine discharge on the Kara Sea during the last deglaciation and the Holocene. Global and Planetary Change 32, 291-309.

Polyakova, Ye.I., 1994. Peculiarities of diatom thanatocoenoses formation in the sediments of the Eurasian Arctic seas. Oceanology 34, 405-414 (English translation).

Polyakova, Ye.I., 1997. The Eurasian Arctic Seas During the Late Cenozoic. Scientific World, Moscow. In Russian.

Polyakova, Ye.I., 2003. Diatom assemblages in the surface sediments of the Kara Sea (Siberian Arctic) and their relationship to oceanological conditions. In: Stein, R., Fahl, K., Fütterer, D.K., Galimov, E.M., Stepanets, O.V. (Eds.), Siberian River Run-off in the Kara Sea: Characterization, Quantification, Variability, and Environmental Significance, Proceedings in Marine Sciences, vol. 6. Elsevier, Amsterdam, pp. $375-399$.

Polyakova, Ye.I., Bauch, H.A., Kassens, H., 2000. Ice-hydrological regime changes in the Late Holocene Laptev Sea. Doklady Earth Sciences 370, 686-688 (Translated from Doklady Akademii Nauk).

Rachold, V., Eicken, H., Gordeev, V.V., Grigoriev, M.N., Hubberten, H.-W., Lisitzin, A.P., Shevchenko, V.P., Schirrmeister, L., 2003. Modern terrigenous organic carbon input to the Arctic Ocean. In: Stein, R., Macdonald, R.W. (Eds.), The Organic Carbon Cycle in the Arctic Ocean. Springer-Verlag, Berlin, pp. 33-56.

Schrader, H.-J., Gersonde, R., 1978. Diatoms. Utrecht Micropaleontological Bulletin 17, 129-176.
Stein, R., 2000. Circum-Arctic river discharge and its geological record: an introduction. International Journal of Earth Science 89, 447-449.

Stein, R., 2001. Lithostratigraphy of gravity cores and correlation with sediment echograph profiles (Akademik Boris Petrov Kara Sea Expeditions 1999 and 2000). Reports on Polar Research 393, $120-140$.

Stein, R., Fahl, K., 2000. Holocene accumulation of organic carbon at the Laptev Sea continental margin (Arctic Ocean): sources, pathways, and sinks. GeoMarine Letters 20, 27-36.

Stein, R., Fahl, K., 2003. The Kara Sea: distribution, sources, variability and burial of organic carbon. In: Stein, R., Macdonald, R.W. (Eds.), The Organic Carbon Cycle in the Arctic Ocean. Springer-Verlag, Berlin, pp. 237-266.

Stein, R., Fahl, K., Dittmers, K., Niessen, F., Stepanets, O.V., 2003. Holocene siliciclastic and organic carbon fluxes in the $\mathrm{Ob}$ and Yenisei estuaries and the adjacent inner Kara Sea: quantification, variability, and paleoenvironmental implications. In: Stein, R., Fahl, K., Fütterer, D.K., Galimov, E.M., Stepanets, O.V. (Eds.), Siberian River Run-off in the Kara Sea: Characterization, Quantification, Variability, and Environmental Significance, Proceedings in Marine Sciences, vol. 6. Elsevier, Amsterdam, pp. 401-434.

Stein, R., Dittmers, K., Fahl, K., Kraus, M., Matthiessen, J., Niessen, F., Pirrung, M., Polyakova, Ye., Schoster, F., Steinke, T., Fütterer, D.K., 2004. Arctic (palaeo) river discharge and environmental change: evidence from the Holocene Kara Sea sedimentary record. Quaternary Science Reviews 23, 1485-1511.

Stuiver, M., Reimer, P.J., 1993. Extended ${ }^{14} \mathrm{C}$ data base and revised CALIB $3.0{ }^{14} \mathrm{C}$ age calibration program. Radiocarbon 35, 215-230.

Stuiver, M., Reimer, P.J., Bard, E., Beck, J.W., Burr, G.S., Hughen, K.A., Kromer, B., McCormic, G., van der Plicht, J., Spurk, M., 1998. INTCAL 98 radiocarbon age calibration, 24000-0 cal BP. Radiocarbon 40, $1041-1083$.

Usachev, P.I., 1968. Phytoplankton of the Kara Sea. In: Syomina, G.I. (Ed.), Plankton of the Pacific Ocean. Nauka, Moscow, pp. 6-28.

Vedernikov, V.I., Demidov, A.B., Sud'bin, A.I., 1995. Primary production and chlorophyll in the Kara Sea in September 1993. Oceanology 34, 630-640 (English translation).

Velichko, A.A., Andreev, A.A., Klimanov, V.A., 1997. Climate and vegetation dynamics in the tundra and forest zone during the late glacial and Holocene. Quaternary International 41/42, 71-96.

Vorobyeva, G.A., 1994. Paleoclimates around Lake Baikal in Pleistocene and the Holocene. Baikal as a Nature Laboratory for Global Change, vol. 2. Lisna Publishers, Irkutsk, pp. 54-55.

Wolfe, B.B., Edwards, T.W.D., Aravena, R., Forman, S.L., Warner, B.G., Velichko, A.A., MacDonald, G.M., 2000. Holocene paleohydrology and paleoclimate at treeline, North-Central Russia, inferred from oxygen isotope records in lake sediment cellulose. Quaternary Research 53, $319-329$.

Zakharov, V.F., 1996. Sea Ice in Climatic System. Gidrometizdat, St. Petersburg. In Russian. 